\title{
IDENTIFYING THE ALTERNATIVE TOURISM POTENTIAL OF THE LAGOONS OF ÇUKUROVA DELTA
}

\author{
Erdinç Balli ${ }^{1}$ \\ Ayşe İpek Koca Balli ${ }^{2}$
}

\begin{abstract}
The objective of this study was to assess the tourism potential of the Lagoons of Çukurova Delta and their surroundings, and identify the different types of alternative tourism activities that could be possible in the region. To this end, the relevant literature was reviewed and observations were conducted in the region. In addition, SWOT analysis was used to identify the strengths and weaknesses of the region, in terms of alternative tourism, as well as opportunities and threats. According to the results, (1) botanical tourism, (2) birdwatching, (3) photo safaris, (4) wildlife observation, (5) trekking, (6) landscape viewing and (7) camping were identified as the major types of alternative tourism activities feasible in the region.
\end{abstract}

Key words: Destination planning, SWOT analysis, Çukurova Delta, tourism.

\section{INTRODUCTION}

The tourism industry constitutes one of the most important sectors in many local economies, mainly because of its constant increasing contribution to the income of these regions, but also due to the opportunities offered for further growth (Karakitsiou et al., 2007). Alternative tourism is essentially a rejection of mass tourism (Lanfant\&Graburn, 1992) which has appeared since 1950's. With its economic, social and cultural consequences it is promoted by the tourist establishment and govermentsespecialy in non-development regions. Alternative tourism is an umbrella term covering wide category of mass tourism alternatives and can be referred to many other names, for example, Soft Tourism, Sustainable Tourism, Green Tourism, and so on. From an sustainable point of view, alternative tourism allows the development of tourism and recreation activities in a country, region or tourist destination by taking into account the basic principles of sustainable development, showing respect for the environment, for the people and for the economy and the local culture of the tourist receiving region (Juganaru, Juganaru\&Anghel, 2008). There are many types of alternative tourism classified in the form of activities or modes of travel. Activity forms include, such as endemic tourism, experience travel, value-added travel, conservation tourism, soft adventure travel, social awareness tourism, ecotourism, community-based tourism, rural tourism so on (Cohen, 1987). Major indication of alternative tourist activities is that "alternative forms of tourism and tourist will have fewer and less

\footnotetext{
${ }^{1}$ Assistant Professor, Department of Hotel Management, School of Karataş Tourism and Hotel Management, University of Çukurova, Adana/Turkey.

${ }^{2}$ Assistant Professor, Department of Businnes, the Faculty of Kozan Business Administration, University of Çukurova, Adana/Turkey.
} 
severe negative effects on destination areas, environment and their populations without diminishing the positive economic effects" (Smith \&Eadington, 1992).

A lagoon is a shallow body of water separated from a larger body of water by barrier islands or reefs. Lagoons, considered the world's natural wealth museums due to the biological variety they host, are the most important ecosystems in the world with their natural functions and economic value. Lagoons:

- by fostering or evacuating subterrenean waters, balance groundwater

- by storing flood waters, leveling floods, inhibiting seawater from getting in shore, regulate the region's water regime

- raise the level of humidity around them and have a positive effect in the local climate elements, especially precipitation and temperature

- clean water by blocking residue and toxic material or by utilizing sustenance (such as nitrogen, phosphorus)

- along with tropical forests, are the most biologically productive ecosystems of the world

- provide a habitat for rich flora and fauna with ecological and high commercial value, especially fish and aquatic birds

- possess high economic value; fishery, agriculture and livestock farming, reed production, tourism and transportation oppurtunities add to regional and national economy (Cagırankaya\&Meric, 2013).

Therefore it can be said; lagoons are special ecosystems of great environmental significance that have many functions, such as regulating the water regime of their region, providing a habitat for endemic plant and animal life and serving as a great resource for economic, cultural, scientific and recreational use.

The objective of this study is to assess the tourism potential of the Lagoons of Çukurova Delta- especially Akyatan and Yumurtalık Lagoons- and their surroundings and identify the different types of alternative tourism activities that could be possible in the region. In addition explain strengths, weaknesses, opportunities and threats of tourism in the region. The study is expected to raise awareness about the tourism potential of the region among stakeholders, including local communities and administrators, as well as evaluating the current situation of tourism in the region and decisions concerning its planning and future.

\section{STUDY AREA}

There are a total of 72 lagoons in Turkey, of which 17 are located in the Mediterranean region. Çukurova Delta located in the northeastern part of the Mediterranean basin and is the biggest of delta of Turkey. It was formed by Seyhan, Ceyhan and Tarsus rivers, which originate in the Taurus Mountains and flow into the Mediterranean Sea. Çukurova Delta contains four lagoons: Akyatan, Yumurtalık, Ağyatan and Tuzla. With 
their ecological treasures and conservation status, two of them -Akyatan and Yumurtal1k- have come to the forefront (Ataol, 2015).

\section{Akyatan Lagoon}

Akyatan Lagoon is the largest lagoon lake in Turkey. Its average area at the average water level is 4.900 ha. Located in Seyhan Delta, the lagoon is 48 kilometers to Adana province and lies within the boundaries of Karataş district. The lagoon has been taken under legal environmental protection status by a decree of the Turkish Government and also protected by the intergovernmental treaty of The Ramsar Convention on Wetlands (Davutluoglu et al., 2010). The Ramsar site comprises various habitats as open water surfaces, reed beds, fresh and saltwater swamps, freshwater puddles, ponds, wide sand dune ecosystems and sandbanks. The lagoon area shrinks in summers due to decrease in water amount feeding the lake and high evaporation.

The largest sand dunes of Turkey - with an elevation of 20 meters and a few kilometers in width - are situated in the region, between Akyatan Lagoon and the Mediterranean Sea. There are pits under sea level, situated among sand mounds that lie in row, which are filled with water during rainy periods. Ecologically important freshwater puddles and swamps that never dry located in the northeast of the sand dunes (Lécuyer et al., 2012). The sand dunes situated between the sea and the lagoons are particularly important for plant species. There are 15 different plant species and 9 different Kinds of forest vegetations in the area (Cagirankaya\&Meric, 2013).

The lagoon is host to many wildlife species. Seyhan Delta coastal sand dunes are very important habitats for lizards, snakes, tortoises, sea turtles, common agama and tree frogs. Striped-neck terrapin and European pond turtle are often found in the freshwater poodles and canals, while tortoises are often found in the sand dunes of Akyatan Lagoon. Montpellier snake, Dahl's whip snake, snake-eyed lizard, mabuyaaurata, chameleon, Crytodactyluskotschyii and Agama stellio are other reptile species the site supports. Reptile species Akyatan Wildlife Improvement Area supports are chameleon, tortoise, ghost crab and blue crabs (Gölge, 2008). Globally endangered green sea turtles (Cheloniamydas) and sea turtles (Carettacaretta) in limited numbers nest in the site (Tapan, 2008). Eirenisaurolineatus, a narrowly distributed snake species particular to Mediterranean biome, is another important reptile species in the site. In Lagoon, totaly 11 fish species have been recorded (Cagirankaya\&Meric, 2013).

Many waterfowls winter in the wetlands in the south of Turkey since wetlands in Central Anatolia freeze in winters. Moreover the site provides groups of numerous avian species in high numbers with feeding and resting areas due to being on the migration route. 250 different bird species were recorded in Akyatan Lagoon and each year between 70,000 and 80,000 water birds winters in this area (Gölge, 2008). Besides globally endangered white-headed duck (Oxyuraleucocephala); the site supports crowded groups of common pochard (Aythyaferina), European wigeon (Anaspenelope), common shelduck (Tadornatadorna), Eurasian coot (Fulicaatra). Another important 
species wintering in the site is flamingo (Pheonicopterusroseus) (Yavuz\&Boyla, 2013).The lagoon is one of the important breeding sites for globally endangered marbled duck (Marmaronettaangustrirostris) as well as rarely seen purple swamphen (Porphyrioporphyrio) and black francolin (Francolinusfrancolinus) (Gölge, 2008).

With its natural formations and artificial habitats created by human intervention, Akyatan Lagoon constitutes appropriate habitats for many mammal species. Wild boar (Susscrofa), jackal (Canis aureus), jungle cat (Felischaus), Egyptian mongoose (Herpestes ichneumon), European hare (Lepus europaeus), and fox (Vulpesvulpes) are the primary mammals the site supports. In addition to these mammals red deer (Cervuselaphus), Indian crested porcupine (Hystrixindica), southern white-breasted hedgehog (Erinaceusconcolor), weasel family (Mustelidae), Trsitram'sjird (Merionestristrami), brown rat (Rattusnorvegicus), black rat (Rattusrattus), Macedonian mouse (Mus macedonicus), Middle East blind mole rat (Nannospalaxehrenbergi) and lesser white- toothed shrew (Crocidurasuaveolens) are relatively rare mammals, the site also supports (Cagırankaya\&Meric, 2013).

\section{Yumurtalık Lagoons}

Yumurtalik Lagoons is positioned within the boundaries of Yumurtalik district of southern Mediterranean city of Adana, except for a small part of it that enters inside the boundaries of Karataş district of the city. The site is located 30 kilometers from the city center of Yumurtalık and 35 kilometers from Karataş. The lagoons are the most important parts of the biggest delta of Turkey, Çukurova wetland ecosystem. There are numerous lakes and lagoons within the site. They are the sub-components of Çamlik, located in the former riverbed of Ceyhan, and Yelkoma, located in the Çamlik Lagoon System comprises Yapı and Ömer Lakes, Çamlık Bay, Darboğaz and Arapboğazı lagoons, which are connected to each other with natural canals. These lakes merge with each other as one lake during winter, when their water levels rise. Yap1 Lake is fed with waters of Ömer Lake, when it floods in winters and dries in summers due to heavy evaporation. The lakes are getting filled rapidly because of sediment load by the streams and canals, flowing from the north. The depth is $0-30 \mathrm{~cm}$ in Yap1 Lake and 30$60 \mathrm{~cm}$ in Ömer Lake.

The site has been taken under protection after being designated as Natural SIT Area 1st degree under the Conservation Law on Cultural and Natural Assets in 1993 and as Nature Conservation Site under the Law on National Parks in 1994. In the year of 2005, Turkish government pledged at an international level to preserve the ecological aspects of the site as it is, by including Yumurtalik in the Ramsar Convention List. Alluviums, dunes, beaches and lakes cover the whole of the conservation site. Alluviums comprising clay, sand, pebble and sporadic swamps are formed by accumulation of the sediments Ceyhan River carries. There are sand mounds in ranges, the height of which rises towards the inland, behind the 0-250-meter breadth beaches. The most virgin 
dunes of the whole Mediterranean exist in Yumurtalık Lagoons (Cagırankaya\&Meric, 2013).

The site is located within the Mediterranean Phytogeographical Region. Yumurtalik Lagoons are located inside the Ceyhan Delta. Aleppo pine forest, Kaldirım Saline and sand dunes are among the important habitats in terms of species. The different dune structures in the site support different floras. The dune plant variety is so rich that it resembles a botanic garden. Plant species and their distribution diverse according to the sand structure. The variety of sand dune vegetation diverse according to their distance to the sea, whether the sand dune is active or permanent, the ground water level and the structure of the sand dune (Gölge,2006).

Wildlife is the leading elements for the site to be qualified as important. In Yumurtalik Lagoons are fish species of 10 families; Six amphibian species of four families and 42 reptile species of 11 families are recorded. Nile softshell turtle (Trionyxtriunguis) copulates at the river mouth and breeds by nesting in the coastal dunes. Yumurtalik Bay is the only known wintering area of endangered green sea turtle (Cheloniamydas) in the Mediterranean (Tapan, 2008).

Lagoons are the important stopover, resting and feeding area on the bird migration roads passing through Anatolia. 252 bird species have been recorded in the site so far. The number of the bird species wintering in the Yumurtalık Lagoons in the past is said to have been more than 70 thousand (Yavuz\&Boyla ,2013). Also region supports 35 mammal species of 12 families (Gölge, 2006).

\section{AIM AND METHOD OF STUDY}

The objective of this study was to analyze the tourism potential of the Lagoons of Çukurova Delta and their surroundings; identify the different types of alternative tourism activities that could be possible in the region and explain current constraints and future possibilities of alternative tourism in the region. For this aim, the relevant literature was reviewed and observations were conducted in the region. In addition, SWOT analysis technique was used in order to explain current constraints and future possibilities of alternative tourism in the region. SWOT stands for strengths, weaknesses, opportunities and threats. A SWOT analysis is essentially a brainstorming session on the key variables that affect a firm's/sector's performance (Henricks, 1999).

\section{FINDINGS}

With its ecological treasures and conservation status, the lagoon region and its vicinity is also suitable for many different kinds of alternative tourism. According to the results, (1) botanical tourism, (2) birdwatching, (3) photo safaris, (4) wildlife observation, (5) trekking, (6) landscape viewing and (7) camping were identified as the major types of alternative tourism activities feasible in the region. 
The results of SWOT analysis of Alternative tourism in Çukurova Delta Lagoon are given below:

\section{Strengths}

- Rich flora and fauna

- The natural and virgin environment.

- Relative protected wildlife

- Easy accessibility

- Extraordinary landscape

- The region weather and climate

- It is located on an important bird migration routes

- Region has four important bird area and a important plant areas

- Two RAMSAR area

- 74 Red List plant species

- 39 animal species in scope of Bern Agreement under protection

- Resources for alternative tourism (especially; botanical tourism, birdwatching, photo safaris, wildlife observation, trekking, landscape viewing and camping)

- Great cultural potential

- Population's hospitality

- Near to main tourist markets geographically

- It is also a new tourism destination.

\section{Weaknesses}

- Disturbed wildlife

- Not suitable Husbandry activities

- Contamination via fertilizers and chemcials used in agricultural lands

- İllegal Hunting

- Disposal solid waste by daily users of the area.

- Lagoons decrease in favor of agricultural areas

- The restriction accommodation of birds

- The natural water regime degradation

- The deterioration of water quality in lagoons

- Reduction of the sandbanks

- Inability to create an attractive image of tourism in region

- Regions biodiversity known not very well from local people

- Lack of information for tourists about the region

- Lack of tourism marketing

- Underdeveloped infrastructure of tourism

- Limited variety and diversification of leisure activities

- Low level of awareness about the environment 
- Limited number of accommodation

- There is no strong community organization in the region for tourism

\section{Opportunities}

- Changes in the preferences of tourists

- Cooperation with neighboring regions for common recreational areas

- Increasing demand of alternative tourism services and flows of tourists

- The possibility to develop sales of ecological agricultural products

- Improvement of the ecological environment

- Routes formation of new recreational and cultural tourism

- The possibility to develop different kind of alternetive tourism

- Increase in the number of TV programs, newpaper and magazine articles focusing on to the area.

- Interest of national/ international environmental protection organizations

\section{Threats}

- The possibility of environmental worsening

- Low population awareness about the environment, ecology

- Global climate change

- Unplanned urban development

- Challenges with natural and cultural heritage protection from the community

- War possibility in neighbor countries (e.g., in Iraq, Syria)

\section{CONSULATION}

The Lagoon Region of Çukurova Delta has habitats with different ecological characteristics, including open water, reeds, freshwater and saltwater swamps, freshwater ponds, lakelets, extensive dune ecosystems, pine forests and beaches. The diversity of the region's habitats enables many plant and animal species to thrive in the region. The region is located on the routes of migratory birds, and is designated a Ramsar Site, a Wildlife Protection Site, a Nature Conservation Area and a Natural Protected Area. With its ecological treasures and conservation status, the lagoon region and its vicinity is also suitable for many different kinds of alternative tourism. According to the results, (1) botanical tourism, (2) birdwatching, (3) photo safaris, (4) wildlife observation, (5) trekking, (6) landscape viewing and (7) camping were identified as the major types of alternative tourism activities feasible in the region. Although described as the world's natural richness museums, the Çukurova Delta Lagoons are exposed to unrecoverable deep damages by the expansion of influence areas of agricultural activities and by planless use. 


\section{REFERENCES}

Books

1. Çağırankaya, S.S \&Meriç, B.T. (2013). Turkey’s Important Wetlands RAMSAR Sites. Ankara: Ministry of Forestry and Water Affairs

2. Gölge M. (2006). Information Sheet on RamsarWetlands (Yumurtalık Lagoons). Ankara: Ministry of Environment and Forestry

3. Gölge M. (2008). Information Sheet on Ramsar Wetlands (Akyatan Lagoon). Ankara: Ministry of Environment and Forestry

4. Lanfant, M. F, \&Graburn, N. H. H (1992) International Tourism Reconsidered: The Principle of the Alternative. In Smith, V. L., and Eadington, W. R. (Eds.), Tourism Alternatives. Philadelphia, PA: University of Pennsylvania Press. pp. 89-112

5. Smith, V., \&Eadington, W. R. (1992). Tourism alternatives: Potentials and problems in the development of tourism. Philadelphia: University of Pennsylvania Press

6. Tapan D. S. (2008). Türkiye'deki RAMSAR alanları değerlendirme raporu, Ankara: WWF-Türkiye

7. Yavuz K. E. \&Boyla K. A. (2013). Türkiye kış ortası sukuşu sayımları, Ankara: Ormanve Su İşleri Bakanlığı

Journal Articles

8. Ataol, M. (2015). Crevasse splay induced avulsion on the Ceyhan Delta. Journal of International Social Research, 8(41).

9. Cohen, E. (1987). Alternative Tourism: A critique. Tourism Recreation Research, 12(2), 13-18.

10. Davutluoglu, O. I., Seckin, G., Kalat, D. G., Y1lmaz, T., \& Ersu, C. B. (2010). Speciation and implications of heavy metal content in surface sediments of Akyatan Lagoon-Turkey. Desalination, 260(1), 199-210.

11. Henricks, M., 1999. Augmented title: Strength- weakness-opportunity-threat analysis. Entrepreneur, 27: 72.

12. Juganaru, I. D., Juganaru, M., \&Anghel, A. (2008). Sustainable tourism types. Annals of University of Craiova, Economic Sciences Series, 2(36), 797-804.

13. Karakitsiou, A., A. Mavrommati, A. Migdalas, and K. Tsiakali, (2007).

Customer satisfaction evaluation in the tourism industry: The case of Chania, Foundations of Computingand Decision Sciences, 32 (2), 111-124.

14. Lécuyer, C., Bodergat, A. M., Martineau, F., Fourel, F., Gürbüz, K., \&Nazik, A. (2012). Water sources, mixing and evaporation in the Akyatan lagoon, Turkey. Estuarine, Coastal and Shelf Science, 115, 200-209. 